\title{
THE STRATEGIC IMPORTANCE OF ENTREPRENEURSHIP AS A MECHANISM FOR SUSTAINABLE ECONOMIC GROWTH IN NIGERIA
}

\author{
Prince Adesanya Abel Segun ${ }^{1}$ \\ Department of Business Administration and Management, \\ Lagos State Polytechnic Ikorodu, Lagos, Nigeria
}

\begin{abstract}
The focus of this paper is on the importance of entrepreneurship as a mechanism for sustainable economic growth in Nigeria considering the experiences of developed nations like the United States, Europe, India, and China. Entrepreneurship has been instrumental in economic growth, balanced regional development, and job creation in most dynamic economies, where technology is changing at a faster rate and the product lifetime cycle is shrinking. Research in entrepreneurship development indicates that there is a lack of a theoretical model to examine rural entrepreneurship development particularly in the developing countries. The methodology adopted in this paper is the narrative - textual case study (NTCS); it is a social science research method that relies on the information and data from several sources for problem-solving. It is undeniable fact that entrepreneurship development plays a vital role in economic development of any nation including the developing countries like Nigeria. However, despite this, most entrepreneurial policies and programs seems to favour the urban cities except recently when efforts are geared towards the rural areas. Thus, this paper examines the role of entrepreneurship in the development of the rural areas in the developing economy. The study reveals that the right business environment for entrepreneurship is lacking in Nigeria on account of bad and inadequate infrastructural facilities, political instability, terrorism, multiple taxes, all stand as barriers to entrepreneurship and economic growth. The paper concludes that government should focus on adequate security, improve infrastructural facilities and enabling environment that will lead to economic growth.
\end{abstract}

Keywords: Nigeria, entrepreneurship, sustainable development, mechanism, and economic growth.

1 Contact Prince Adesanya Abel Segun, (PhD) asetaded2nd62@gmail.com, Department of Business Administration and Management, Lagos State Polytechnic Ikorodu, Lagos, Nigeria. 


\section{Introduction}

Entrepreneurship in Nigeria started when people in the villages and farming communities produced more products than they needed, as such; they had to exchange these surpluses with those who needed them within their immediate and neighbouring communities. The exchange of goods for goods or services was based on trade by barter initially, until commodity money was developed and used. Exchange encouraged specialisation among producers, and the communities came to realise that they can concentrate on the areas of production they are best fitted for. Consequent on the above, the culture of entrepreneurship started in Nigeria (Nicks, 2008; Raimi \& Towobola, 2011).

The developed countries have long before now regard entrepreneurship and small scale enterprise as the best means of reducing poverty and sustaining their economy while the developing countries have just turned to these sectors (SME) as a strategy to reduce poverty and increase economic growth because entrepreneurship is a seed bed of innovations, inventions, and employment. The socio-economic impact of entrepreneurship on the sustainable economic growth of the Nigerian economy is difficult to accurately measure or estimate, but it is believed to be highly dynamic and significant (Chu, Kara, Benzing, \& Cynthia, 2010).

On account of encouraging entrepreneurial initiatives, the country has experienced growth in the number of private enterprises. However, majority of these businesses are very small when their operations are measured in terms of capital, employment, and revenues (Attahir \& Minet, 2000). Added to the above is difficulty confronted by small businesses in accessing bank credits, but the most serious and damaging problem threatening the state of entrepreneurship in Nigeria is a lack of government interest and support for micro, small enterprises (Ariyo, 2005; Chu et al., 2008). In addition, entrepreneurship and small and medium enterprises development is hampered by many challenges like bad roads, bribes by government officials, multiple taxes, epileptic power supply, rising overhead cost, the global economic meltdown and global pandemic. All these challenges and similar others have attracted global attention. The informal sector, which largely comprises the small scale enterprises in trade, services, agricultural and non-agricultural business, is estimated to provide $80 \%$ of jobs in rural and urban centres. Unfortunately this sector, remain at the subsistence level due to poor motivation, non-availability of basic infrastructural facilities and poor enabling environments.

This article, therefore, discusses how Nigeria can attain a sustainable economic growth through the effort of the entrepreneurs and the government. The broad objective of this paper is to highlight the challenges facing entrepreneurship and sustainable economic growth in Nigeria using 
NTCS Analysis. With the challenges highlighted, realistic recommendations would be proffered for the nation to move forward.

\section{Literature review}

Theoretical evolution, many believe that entrepreneurship is the driving force behind organisation since it coordinates other factors of production. Many economists accept the idea that entrepreneur is, since the time of Marshal, the concept of entrepreneurship has continued to undergo innovators, this theory however is not applicable to less developed countries because entrepreneurs in less developed countries rarely produces brand new product rather they imitate the product and production process that have been invented in mostly developed countries.

There is no adequate literature that explores entrepreneurship and economic growth in Nigeria, hence reliance is on materials from developed and developing countries for a deep insight into the impact of entrepreneurship on sustainable economic growth and development. Entrepreneurship is the creation and management of a new organisation designed to pursue a unique, innovative opportunity and achieve rapid, profitable growth (Shane and Venkataraman, 2000). Kanothi (2009) as cited by Vale (1990) defines entrepreneurship as "an unrehearsed combination of economic resources instigated by the uncertain prospect of temporary monopoly profit". Entrepreneurship also entails the act of risk-taking, innovation, arbitrage and co-ordination of factors of production in the creation of new products or services for new and existing users in human society (Acs \& Storey, 2004; Minniti \& Lévesque, 2008; Naudé, 2007; Kanothi, 2009). The deliverable of entrepreneurship is making or doing things differently; making or providing innovative products or services; or organizing how the products are made or supplied

Awodun (2008) adopted the same approach in his effort to describe entrepreneurship; he saw entrepreneurship as an act of the recognizing opportunities in one's environment. Mobilising resources to take advantage of such opportunities, Ensuring the provision of new or improved goods and services to consumers; and obtaining profit in return for the risk to dare. Ogundele OJk (2007), views entrepreneurship as a process of performing the entrepreneurial functions overtime in a given environment. Lawal, Kio, Sulaimon and Adebayo (2006) refer, to entrepreneurship as the act or process of identifying business opportunities and organizing to initiate a successful business activity. From the above definitions it can be seen that entrepreneurship is the process of initiating a business enterprise using available resources within the immediate environment and nurturing it to a successful end. Initiating an enterprise is best done through Nano, micro-small medium enterprise. 
According to Kindleberger (1977) as cited by Akosile, Adesanya, Ajani (2012) economic growth is defined as an increase in the macroeconomic variables like increase in the nation per-capita income, expansion in labour force, consumption pattern and volume of trade. Economic growth is the increase in the value of the goods and services produced by an economy. It is conventionally measured as the percent rate of increase in real gross domestic product, or GDP (Jones, 2002). Growth is usually calculated in real terms, i.e. inflation-adjusted terms, in order to net out the effect of inflation on the price of the goods and services produced. In economics "economic growth" or "economic growth theory" typically refers to growth of potential output, i.e., production at "full employment," which is caused by growth in aggregate demand or observed output (Erbee \& Hagemann, 2002). The link between entrepreneurship as a catalyst for sustainable economic growth has been over discussed in the literature.

During the days of the British Empire, the UK economy was the largest in the world and the first to industrialise, though this led to industrial revolution and it has declined in significance, but the UK is still the sixth largest economy in the world by purchasing power parity. GDP growth was 1.1 per cent in 2008, but it is expected to contract in coming years, with GDP growth forecasts of -3.2 per cent in 2009 and -1.1 per cent in 2010. The UK has a population of $61 \mathrm{~m}$ and a GDP per capita is US\$ $37.4 \mathrm{k}$, which makes it the $30^{\text {th }}$ richest country in the world, above the European Union average of US\$ 33.8k (Economy Watch, 2010). Market liberalisation in the Chinese Economy has brought its huge economy forward by leaps and bounds. China's economy is huge and expanding rapidly. In the last 30 years the rate of Chinese economic growth has been almost miraculous, averaging $8 \%$ growth in Gross Domestic Product (GDP) per annum. The economy has grown more than 10 times during that period, with Chinese GDP reaching 3.42 trillion US dollars by 2007. In Purchasing Power Parity GDP, China already has the biggest economy after the United States. Most analysts project China to become the largest economy in the world this century using all measures of GDP (Economy Watch, 2010). The smaller public sector is dominated by about 200 large state enterprises concentrated mostly in utilities, heavy industries, and energy resources (China Daily, 2006).

India, an emerging economy, has witnessed unprecedented levels of economic expansion, along with countries like China, Russia, Mexico, and Brazil. India, being a cost effective and labour intensive economy, has benefited immensely from outsourcing of work from developed countries, and a strong manufacturing and export oriented industrial framework. With the economic pace picking up, global commodity prices have staged a comeback from their lows and global trade has also seen 
healthy growth over the last two years (Economy Watch, 2010). Indian economy has been predicted to grow at a level of $6.9 \%$. Growth in the Indian economy has steadily increased since 1979 , averaging $5.7 \%$ per year in the 23-year growth record. In fact, the Indian economy has posted an excellent average GDP growth of 6.8\% since 1994 (the period when India's external crisis was brought under control). Many factors are behind this robust performance of the Indian economy in 2004-05. High growth rates in Industry \& service sector and a benign world economic environment provided a backdrop conducive to the Indian economy. Another positive feature was that the growth was accompanied by continued maintenance of relative stability of prices (Economy Watch, 2007).

Studies indicate that small enterprises are the leading force in the development of African economies and are essential for economic growth in many developing countries (Chu, Kara, \& Benzing, 2010). Entrepreneurial initiatives especially innovation, risk bearing, employment creation, new opportunities identification and the commercialisation of results of inventions have indeed contributed to the prosperity in many regions of the world (Schumpeter, 1950; Ukaegbu, 2000; Chu, Kara, \& Benzing, 2008). In Africa, the contribution of entrepreneurship cannot be underscored. For instance, Ghanian micro-enterprises employ less than 5 people, yet accounted for 70 percent of country's workforce (Government of Ghana, 2003; World Bank, 2006). Similarly, Kenya's private SMEs sector employed 3.2 million people and contributed 18 percent to the nation's GDP (OECD, 2005).

Nigeria has not been able to experience accelerated growth because it is a mono-product economy with the large proportion of government revenue coming from oil wealth, while numerous other solid minerals remain unexploited and untapped. The economy has disproportionately relied on the primary sector (subsistence agriculture and the extractive industry) without any meaningful value addition to growth and development. Consequently, the little growth recorded in the economy, so far, has been without commensurate employment, positive attitudinal change, value reorientation, and equitable income distribution, among others. These bleak growth indicators could be attributed to poor leadership, poor implementation of economic policies, weak institutions, poor corporate governance, endemic corruption, et cetera (Sanusi, 2001).

The challenge, therefore, is how will Nigeria get out of the economic mess considering the bulk of challenges and it seems no solution in sight, however the support given to the entrepreneurs of small medium enterprises by the Central Bank of Nigeria may go a long way if properly implemented to cause a gradual economic growth. 


\section{Entrepreneurship development}

In an attempt to defined entrepreneurship development, Darren \& Conrad (2009) described entrepreneurship as a process where an individual discovers, evaluates opportunities independently. In a similar manner, Ogundele (2007) sees entrepreneurship as a process involving recognising opportunities in the environment, mobilising resources to take advantage of such opportunities in order to provide improved goods and services for consumers and making as a reward for risk taken. Therefore, entrepreneurship is all about environmental opportunities that are waiting to be tapped. Accordingly. It is a process of creating something new and assuming the risks and rewards (Hisrich \& Peters, 2002). There are four essential elements used in those definitions: creative process, risk taken, rewards, time, and effort.

Robert et al. (2008) as cited by Esuh Ossai-Igwe Lucky (2012) noted that entrepreneurship is the creation of something new and assuming the risk and rewards. Entrepreneurship is therefore all about learning the skills needed to assume the risk of establishing a business and developing the winning strategies and executing them with all vigour, persistence and passion needed to win any win any game (Rebecca et al., 2009). The authors stressed the need for entrepreneurs/firm owners to learn new skills that would aid the firm performance. Therefore, an entrepreneur must possess some skills if he or she is to achieve a significant firm performance. Rebecca et al. (2008) Esuh Ossai-Igwe Lucky (2012) further concluded that entrepreneurship is simply concerned with what an entrepreneur actually does - the utilisation of resources in managing an enterprise and assuming the risks and maximising profit from the business venture. They affirmed that entrepreneurship is a dynamic process of creating wealth for the well-being of both the entrepreneurs and individuals in the society. Therefore, successful entrepreneurship requires the entrepreneur to possess certain managerial skills. These skills according to Rebecca and Benjamin (2009) among others are ability to learn new techniques in handling business operation, ability to adopt to change and to handle changes in the environment.

From the above, it could be observed that authors have used one or more criteria to define the concept of entrepreneurship. Many stressed the need for learning new skills and techniques, recognising opportunities, mobilising resources, an act or process, rewards, taken of risk and creation of wealth. However, none has recognised the importance of nurturing entrepreneurship. Therefore, entrepreneurship definition can be better appreciated if the word "nurturing" was included. It can be seen as the process of nurturing entrepreneurship, as well as the entrepreneur from the grassroots to recognise opportunities in the environment so as to mobilise resources, by taking risk in order to create wealth and at the same time making profit through effective and efficient management of the business. 
In the light of this, Arowomole (2000) defined entrepreneurship as the coming into existence in the society or country of the class of individuals, who are not timid to face odds and ready to achieve a significant performance. Accordingly, Amit, Glisten and Muller (1993) defined entrepreneurship development as the process of extracting profit (firm performance) from new, unique, and valuable combination of resource in an uncertain and ambiguous environment.

Considering this definition, entrepreneurship development, could equally be seen as a gradual process in which an individual takes in establishing a business or creating wealth for the purpose of making profit. This may be in line with Amit et al. (1993)'s submission as both definitions is concern with the issue of profit, wealth creation and firm performance.

Therefore, entrepreneurship involves the process of nurturing the actual or potential entrepreneurs to become effective in running their own organisations ensuring how well the firm performs in its business operations and this has to be done at various stages and in various institutions. From the ongoing, it is clear that entrepreneurship is a process and not SMEs. Thus, it is a process to the establishment and creation of SMEs or business ventures. Entrepreneurship process leads to the birth of SMEs and business ventures in many sectors being it manufacturing, services, wholesale, or retail.

\section{Economic growth in Nigeria}

The Nigerian economy is one of the most developed economies in Africa. According to the UN classification, Nigeria is a middle-income nation with developed financial, communication and transport sectors. It has the second largest stock exchange in the continent. The petroleum industry is central to the Nigerian economic profile. It is the $12^{\text {th }}$ largest producer of petroleum products in the world. The industry accounts for almost $80 \%$ of the GDP share and above $90 \%$ of the total exports. Outside the petroleum sector, the Nigerian economy is highly amorphous and lacks basic infrastructure. Several failed efforts have been made after 1990 to develop other industrial sectors (Economy Watch, 2010) Nigeria has great potentials for economic growth and development, given her vast natural resources in agricultural lands and minerals, as well as abundant manpower. In the last two decades, economic growth rate has been very low and in many years less than the population growth rate.

The general macroeconomic outcome has been poor, resulting to high poverty level (Wikipedia, 2010). GDP per capita of Nigeria expanded $132 \%$ in the 1960 s reaching a peak growth of $283 \%$ in the 1970 s. But this proved unsustainable and it consequently shrank by $66 \%$ in the 
1980s. In the 1990s, diversification initiatives finally took effect and decadal growth was restored to $10 \%$. Due to inflation, per capita GDP today remains lower than in 1960 when Nigeria declared independence. About 57 percent of the population lives on less than US\$ 1 per day. In 2005 the GDP real growth rate was $6.90 \%$ composed of the following sectors: agriculture, 26.8 percent; industry, 48.8 percent and services, 24.4 percent. Compare to 2009 GDP of $3.80 \%$, composed of agriculture, 33.4 percent; industry, 34.1 percent; and services, 32.5 percent (CIA World Fact book, 2010). The low growth rate deals with downsizing of the industrial sector in Nigeria.

One factor that impacted negatively on growth was high lending interest rates which promoted savings, but discouraged the flow of credit and investments to the real sector. Another economic phenomenon that affected growth was large budget deficits that were financed by the banking sector. Deficit/GDP ratio averaged 4.7 per cent in the last decade. The high level of deficit financing meant that the bulk of credit available to the economy was diverted to funding government, thus crowding out the private sector in the credit market. The most serious problem was inflationary pressure that devalued the currency and induced uncertainty that made entrepreneurs to postpone investment decisions. Inflation promoted the diversion of resources from productive to speculative activities with serious consequences for employment and growth (United Nations, 2003). The following are the most recent data on the growth rates of major sectors in Nigeria for period 2008-2009.

Table 1. Growth Rates of Major Sectors in Nigeria, 2019

\begin{tabular}{|l|c|c|}
\hline \multicolumn{1}{|c|}{ Sector } & $\mathbf{2 0 1 8}(\%)$ & $\mathbf{2 0 1 9}(\%)$ \\
\hline Agriculture & 6.3 & 6.2 \\
\hline Mining and Quarrying & -5.9 & -1.0 \\
\hline Manufacturing & 8.9 & 8.5 \\
\hline Electricity, Gas and Water & 4.0 & 3.6 \\
\hline Construction & 13.1 & 12.9 \\
\hline Wholesale and Retail trade, Restaurants, Hotels & 14.0 & 11.6 \\
\hline Finance, Insurance, Real Estate etc & 6.8 & 6.4 \\
\hline Transport and Communication & 19.3 & 20.9 \\
\hline Public Administration and Defence & 4.4 & 4.5 \\
\hline Other Services & 10.3 & 10.0 \\
\hline
\end{tabular}

Source: African Statistical Yearbook 2019 by African Development Bank. 
Table 2 below gives more insights into the nation's economic performance from 2010-2019. The real GDP in 2010, 2011, 2014, 2017 and 2019 were $3.8,3.5,7.1$ and 5.3 respectively. This indicates a zigzag and inconsistent economic growth in Nigeria. The dividend of real GDP growth even when there is an increase has not been judiciously used for sustainable economic programme like entrepreneurship development and small business promotion. Consequently, the capacity utilisation of the economy from 2010 to 2019 fluctuated between 36\% and 50\%. This has been blamed largely on frequent power outages, multiple taxes and other challenges to entrepreneurship development (BEEPS, 2020).

Table 2. Nigeria: Performance of the Economy, 2010-2019

\begin{tabular}{|l|c|c|c|c|c|c|c|c|c|c|c|}
\hline & 2010 & 2011 & 2012 & 2013 & 2014 & 2015 & 2016 & 2017 & 2018 & 2019 & 2019 \\
\hline $\begin{array}{l}\text { Real GDP } \\
\text { Growth (\%) }\end{array}$ & 3.8 & 3.5 & 3.5 & 3 & 7.1 & 6.2 & 6.9 & 5.3 & 6.4 & 5.3 & 6.8 \\
\hline $\begin{array}{l}\text { Population } \\
\text { Growth (\%) }\end{array}$ & 2.67 & 2.61 & 2.54 & 2.53 & 2.45 & 2.37 & 2.38 & 2.379 & 2.025 & 1.99 & 2.0 \\
\hline $\begin{array}{l}\text { Unemployment } \\
\text { Rate (\%) }\end{array}$ & 3.6 & 28.0 & 28.0 & 28.0 & 28.0 & 4.9 & 2.90 & 5.80 & 4.9 & 4.9 & 4.9 \\
\hline $\begin{array}{l}\text { Manufacturing } \\
\text { Capacity } \\
\text { Utilization }\end{array}$ & 36.1 & 42.7 & 54.9 & 56.05 & 55.7 & 55.88 & 53.3 & 4.6 & NA & NA & NA \\
\hline $\begin{array}{l}\text { Inflation } \\
\text { Rate (\%) }\end{array}$ & 6.9 & 16.6 & 12.9 & 14.20 & 13.80 & 16.50 & 13.50 & 10.50 & 5.40 & 11.60 & 11.50 \\
\hline
\end{tabular}

Source: The Central Bank of Nigeria, 2010-2019.

\section{Methodology}

The methodology employed in this article is the narrative-textual case study (NTCS) method, which is preferred because of the absence of sequential data related to entrepreneurship and sustainable economic growth in Nigeria. NTCS is a social science research method that employs intensively, the information, data and academic materials made available and easily accessible by information and communication technology facilities such as intranet, internet, World Wide Web, online databases, e-libraries et cetera (Abou Zeedan \& Leijon, 2007).

The choice of this method is informed by the fact that NTCS combines the use of quantitative and qualitative observation, text content analysis and available official statistics in different proportions for problem-solving or problem-identification depending on the objectives of the research (Ibid). 


\section{Findings}

\section{Challenges Affecting Economic and Entrepreneurship Development}

Nigeria despite its abundant natural and human resources is unfortunately faced with some challenges which in the recent years have surged appreciably cause serious set-backs to entrepreneurship development. With specific reference to the SMEs, they are faced frequently harassment from the government officials who extorted money from their businesses. In addition, there is paucity of infrastructure including bad roads, water shortage, erratic supply of electricity, and poor telecommunication system (Mambula, 2002; Chu, Kara, \& Benzing, 2008). Added to the above discouraging challenge is difficulty accessing bank credits, but the most serious and damaging problem threatening the state of entrepreneurship in Nigeria is a lack of government interest and support for micro, small enterprises (Ariyo, 2005; Chu et al., 2008). Furthermore, the Business Environment and Enterprise Performance Surveys (2007) identified fifteen (15) critical challenges facing businesses in Nigeria. These include: access to finance, access to licenses/permit, corruption, courts, crime/theft/ disorder, customs \& trade registration, electricity, inadequately educated workforce, labour regulations, political stability, practices informal sector, tax administration, tax rates and transportation. The responses of the firms have also been clearly analysed according to operational sizes (small, medium, and large) as shown below.

Table 3. Critical Challenges Facing Businesses in Nigeria

\begin{tabular}{|l|c|c|c|c|}
\hline Challenges of SMEs in Nigeria & $\begin{array}{c}\text { Nigerian } \\
\text { (\%) }\end{array}$ & $\begin{array}{c}\text { Small } \\
\text { (\%) }\end{array}$ & $\begin{array}{c}\text { Medium } \\
(\mathbf{\%})\end{array}$ & $\begin{array}{c}\text { Large } \\
\text { (\%) }\end{array}$ \\
\hline Access to Finance & 15.55 & 17.01 & 11.52 & 3.90 \\
\hline Access to Land & 2.85 & 2.70 & 3.38 & 2.85 \\
\hline Licenses and Permit & 0.57 & 0.58 & 0.60 & 0.00 \\
\hline Corruption & 1.87 & 2.13 & 1.12 & 0.00 \\
\hline Courts & 0.00 & 0.00 & 0.00 & 0.00 \\
\hline Crime, Thefts and Disorder & 2.07 & 1.64 & 3.40 & 4.33 \\
\hline Customs \& Trade Registration & 1.31 & 1.09 & 2.23 & 0.00 \\
\hline Electricity & 63.63 & 62.66 & 65.50 & 78.78 \\
\hline Inadequately educated work force & 0.31 & 0.32 & 0.32 & 0.00 \\
\hline Labour Regulation & 0.09 & 0.07 & 0.20 & 0.00 \\
\hline Political Instability & 0.70 & 0.79 & 0.45 & 0.00 \\
\hline Practices Informal Sector & 1.05 & 0.92 & 1.66 & 0.00 \\
\hline
\end{tabular}




\begin{tabular}{|l|c|c|c|c|}
\hline Challenges of SMEs in Nigeria & $\begin{array}{c}\text { Nigerian } \\
(\mathbf{\%})\end{array}$ & $\begin{array}{c}\text { Small } \\
\mathbf{( \% )}\end{array}$ & $\begin{array}{c}\text { Medium } \\
\mathbf{( \% )}\end{array}$ & $\begin{array}{c}\text { Large } \\
\text { (\%) }\end{array}$ \\
\hline Tax administration & 0.28 & 0.12 & 0.49 & 3.47 \\
\hline Tax Rates & 2.24 & 2.11 & 2.70 & 2.49 \\
\hline Transportation & 7.49 & 7.88 & 6.42 & 4.16 \\
\hline
\end{tabular}

Source: Business Environment and Enterprise Performance Surveys (BEEPS)/World Bank, 2020.

More importantly, a survey conducted by the Manufacturers Association of Nigeria (MAN) lends credence to BEEPS/World Bank 2007 survey. The recent MAN survey reveals that a total of 834 manufacturing companies closed down their operations in 2019. This is consequent upon the companies' inability to cope with the challenges high overhead cost and unfriendly business environment (Punch, 2017; The Nation, 2018). The closed down of 834 companies in Nigeria was attributable to epileptic power supply, high cost of alternative sources of electricity and multiple taxes, which resulted in huge cost of doing business. The closure of these companies has further compounded the already bad state of unemployment in the nation (The Nations, 2018). Typical taxes payable in Nigeria include: public convenience fee, sewage and refuse disposal fees, customary burial ground permit fees, religious places establishment permit fees, signboard and advertisement fees and radio, television license fees other than radio and television transmitter (Daily Triumph, 2018). The total figures of 834 closed down companies represent the cumulative aggregate of firms that shut down their operations in 2009 across the country. The geographical breakdown of companies during the period is as follows: 176 firms collapsed in the Northern zone covering the Kano and Kaduna states manufacturing axis; 178 companies closed down in the south-east zone; 46 companies shut down operations in the south-south zone consisting of Rivers, Cross River and Akwa Ibom states; 225 companies closed down in the south-west area, which comprises Oyo, Ogun, Osun, Ondo, Ekiti, Kogi and Kwara states; and 214 manufacturing firms closed down in Lagos zone covering Ikeja, Apapa, Ikorodu and other industrial divisions in the "Centre of Excellence".

\section{Conclusion/recommendations}

Economic growth is the key to higher living standards. According to Onipede (2003), economic theory suggests several key institutions and policy factors that are important for the achievement of maximum economic growth. It is therefore recommended that the following institutions and policies be enhanced in order to make way for sustainable economic and entrepreneurship development in Nigeria: 
1. There is the need for security of property right and political stability in the country. A volatile political, religious, and ethnic climate undermines security of property rights.

2. Stable money and prices are essential for development. A stable monetary environment provides the foundation for the efficient operation of a market economy. In contrast, monetary and price instability generate uncertainty and undermine the security of contracts.

3. The market and enabling environment must be competitive. In a competition, producers must woo consumers away from other suppliers. To do so, they must offer quality and cheaper alternatives. Sellers who cannot provide quality products at competitive prices have no place in a competitive market economy and thus would be driven from the market (Gwartney et al., 1999).

4. There must be in place policy and regulations that guarantee freedom of trade, within or without. Trade is very important for growth and prosperity. When the citizens are allowed unfettered right albeit within the permissible confines of the law to buy from suppliers offering the best deal and sell to purchasers willing to pay the most attractive prices, this way, they would be able to concentrate on the things they do well, while trading for those they do poorly (Gwartney et al., 1999). Theoretically Nigeria is an open economy, which is on the face value; however, the opposite is the reality as there are many legal barriers in place, which make free trade next to impossible. These barriers should, as a matter of utmost importance be reviewed and where possible, expunged totally (Onipede, 2003).

5. Information communication technology (ICT) must be optimally utilised. ICT is a term that encompasses all forms of technology used to create, store, exchange and use information in its various forms (Business Data, Voice, Conversation, still images, Motion Pictures, Multimedia presentations and other forms, including those not yet conceived). It is the technology that is driving - "information revolution". It is an enabler as e-Business e-Commerce and e-Service.

6. Right-sizing of government. Government can meaningfully enhance economic growth by providing an infrastructure for the smooth operation of markets. A legal system that provides price stability is the central elements in this area (Gartney et al., 1999). However, a government that grows too large as the case is in Nigeria, retards economic growth in a number of ways. First, as government grows, relative to the market sector, the returns to government activities diminish. The larger the government, the greater is its involvement in activities it does poorly. Second, more government means higher taxes, as the government fails to provide basic essential infrastructures for a better standard of living of its citizens. However, as taxes take 
more earnings from citizens, the incentive to invest declines. Third, compared to the market sector, government is less innovative and Less responsive to change (Onipede, 2003). Innovation is one of the major ways of creating job for people in Nigeria.

Most of the researches from educational and research institutions in developed countries are to solve problems of industries. This is done by Partnership among the elements in the national innovation system (NIS). The major elements in the national innovation system are: Education Institution: This is to generate knowledge-economy. Research and development Institution: generates research results for technology adaptation, and for commercial purposes. Firms and Industries Institution: the commercialisation of the industrial products. Government and financial institution: are to give incentive and fund the other elements. Development of entrepreneurial skills married with excellent knowledge of information and communication technology (ICT) as additional key to technological and entrepreneurial development is important.

Nigeria's vision of achieving sustainable economic growth and social development will remain unrealised if the nation's infrastructural needs are not addressed. The provision of infrastructure such as power, transport and water are vital. Without adequate, cheap, constant and reliable electric power supply, no technological development will be successively achieved. New innovation is lacking in Nigeria, most entrepreneurs prefer to import goods and package for sales because of high cost of production. In order to reverse this trend, it is pertinent that government gives priority to capacity building for technological innovation, good infrastructure and provide environment conducive for business that will lead to sustainable economic growth. Additionally, since entrepreneurs are vital to economic growth, legislators and other leaders who develop economic policies should strive to encourage the innovation and risk taking of entrepreneurs. Enforcing property rights through contract, patent, and copyright laws; encouraging competition through free trade, deregulation and antitrust legislation and promoting a healthy economic climate. Any country that lacks capacity for production of goods will become a consuming nation instead of an industrial nation. Finally, the Nigerian government needs to shift from overdependence on oil and place more attention on the development of small \& medium sized enterprises for sustainable economic growth in Nigeria. Economic prosperity in Nigeria, as in the rest of the world, depends on strong and empowered private sector to lead MSEs to a higher level of growth which would significantly contribute to the country's economic well-being. 


\section{REFERENCES}

Abouzeedan, Adli, \& Leijon, Svante (2007). Critical review of the usage of narrativetextual case studies in social sciences and the connect to traditional research methods. Paper presented at the 10 Uddevalla Symposium, 14-16 June, Uddevalla, Sweden. Research Report, University West.

Acs, Z.J., \& Storey, D.J. (2004). Introduction: Entrepreneurship and Economic Development. Regional Studies, 38(8): 871-877.

African Statistical Yearbook 2010 by African Development Bank.

Akosile, I.O., Adesanya, A.S., \& Ajani, A.O. (2012). Management of Development (A Nigerian Perspectives). Lagos Nigeria. Olas Ventures.

Alan, Beattie (2010). False Economy - A surprising economic history of the world. Penguin Books. ISBN: 978-0-141-03370-9.

Ariyo, D. (2005). Small firms are the backbone of the Nigerian economy. Retrieved Nov. 8, 2005, from http://www.africaeconomicanalysis.org

Binks, M., \& Vale, P. (1990). Entrepreneurship and Economic Change. London: McGraw Hill.

Brouwer, M.T. (2002). Weber, Schumpeter and Knight on Entrepreneurship and Economic Development. Journal of Evolutionary Economics, 12, 83-105.

Business Environment and Enterprise Performance Surveys. (2007). Problems and Challenges of Small Medium Enterprises.

Central Bank of Nigeria. (2000-2010). Staistical Bulletin - Performance of the Economy, 2000-2010.

China Daily. (2006). China's GDP Grows $10.7 \%$ in 2006, Fastest in 11years. China Daily, Thursday, January 26. Available on http://www.chinaDaily.com (last accessed July 8, 2008).

Chu, Hung M., Kara, Orhan, \& Benzing Cynthia (2010). An empirical study of Nigerian entrepreneurs: success, motivations, problems, and stress. International Journal of Business Research. FindArticles.com. 16 Aug.

Chu, Hung M., Kara, Orhan, \& Benzing Cynthia (2008). An empirical study of Nigerian entrepreneurs: success, motivations, problems, and stress. International Journal of Business Research. FindArticles.com. 16 Aug, 2010. http:/findarticles.com/p/articles/ mi_6773/is_2_8/ai_n31121252/

CIA World Factbook. (2010). Nigeria Economy 2010. Available: www.theodora.com/ wfbcurrent/nigeria/nigeria_economy.html

Daily Triumph (2011). Manufacturers Association of Nigeria laments burden of numerous taxes. http:/www.triumphnewspapers.org/maans2332011.html

Economy Watch. (2007). Indian Economy Overview. Available: support@ economicwatch.com.

Economy Watch. (2010). China Economy. Available: www.economywatch.com/wiorld economy/china

Economy Watch. (2010). Indian Economy Overview. Available: www.economywatch. com/indianeconomy/indian-economy-overview.html

Economy Watch. (2010). Nigeria Economy. Available: www.economywatch.com/world economy/Nigeria 
Economy Watch. (2010). UK Economy. Available: www.economy watch.com/world economy/united-kingdom (last accessed September 22, 2010).

Erber, G., \& Hagemann, H. (2002). Growth, Structural Change, and Employment. In: Frontiers of Economics. Ed. Klaus F. Zimmermann. Springer - Verlag, Berlin Heidelberg - New York, 269-310.

Esuh Ossai-Igwe, Lucky. (2012). Is Small and Medium Enterprise (SME) an Entrepreneurship? International Journal of Academic Research in Business and Social Sciences, January, Vol. 2, No. 1. ISSN: 2222-6990 341, www.hrmars.com/journals

Government of Ghana. (2003). National Medium Term Private Sector Development StrategyVolume1: Strategy. Available on http://findarticles.com/p/articles/mi_6773/ is_2_8/ai_n31121252/

Gwartney, J.D., Lawson, R.A., \& Holcombe, R.G. (1999). Economic Freedom and the Environment for Economic Growth.Journal of Institutional and Theoretical Economics, 155(4), 134-148.

Jöhr, H. (2005). The Potential Contribution of Swiss Multinational Companies to Sustainable Economic Growth in Africa. Available: http://www.nestle.com/our responsibility/Africa/Report.html

Jones, C.I. (2002). Introduction to Economic Growth. $2^{\text {nd }}$ ed. W.W. Norton \& Company: New York, N.Y.

Kanothi, Raphael Ngatia (2009). The dynamics of entrepreneurship in ICT: Case of mobile phones downstream services in Kenya. Working Paper, No. 466. Institute of Social Science, The Netherlands.

Lawal, A.A., Kio, J.S., Sulaimon, A.A., and Adebayo, I.O. (2006). Entrepreneurship development in small scale business. Lagos. Akolaz ventures.

Minniti, M., \& Lévesque, M. (2008). Recent developments in the economics of entrepreneurship. Journal of Business Venturing, 23: 603-612.

Naudé, W. (2007). Peace, Prosperity, and Pro-Growth Entrepreneurship. Helsinki: United Nations University.

Nicks (2008). The History of Entrepreneurship in Nigeria. http://bizcovering.com// history/the-history-of-entreprenership-in-Nigeria

OECD Development Centre. 2005. African Economic Outlook (2004-2005).

Onipede, S. (2003). Towards Creating an Environment for Sustainable Economic Growth in Nigeria, International Experience. Available: http://www.economist. $\mathrm{com} /$ countries/Nigeria/profile.cfm?folder $=$ profile-Economic $\% 20$ structure.

Phoenix, A.Z. (2006). The Crucial Role of Entrepreneurship in the Economy. ArriveNet. U.S Newspaper. Tuesday, February 07. Available: http://www.ArriveNet.US/ Newspaper.html

Punch (2010). How 834 companies closed down in Nigeria. Vol. 17, No. 19, 610.

Raimi, L., \& Towobola, W.L. (2011). Open Distance Learning (ODL): A Catalyst For Educational and Entrepreneurship Development in Nigeria. Continental Journal of Education Research, 4(3): 1-11.

Rebecca, E.O., \& Benjamin, J.I. (2009). Entrepreneurial competencies: The missing links to successful entrepreneurship in Nigeria. International Business Research, 2(2), $62-71$. 
Sanusi, Lamido Sanusi (2010). Growth Prospects for the Nigerian Economy. Convocation Lecture delivered at the Igbinedion University Eighth Convocation Ceremony, Okada, Edo State, Nigeria.

Schumpeter, J.A. (1950). Capitalism, socialism, and democracy. New York: Harper and Row. Journal of Sustainable Development Studies.

Shane, S., \& Venkataraman, S. (2000). The Pro mise of Entrepreneurship as a Field of Research. Academy of Management Review, 25(1), 217-226.

The Nations (2011). Big challenge - How 834 companies closed down in Nigeria. http://thenationonlineng.net/web3/editorial/28749.html.

Ukaegbu, C.C. (2000). Working conditions and employee commitment in indigenous private manufacturing firms in Nigeria: managing business organizations for industrial development. The Journal of Modern African Studies, 38, 295-324.

United Nations. (2003). Human Development Reports, CIA World Factbook. World Bank, pp. 1-2, December. Available: www.theodora.com/wfbcurrent/.../nigeria economy.html

Wikipedia. (2010). Nigeria Economy. Available:

World Bank. (2006). Ghana: World Bank Support Micro, Small and Medium Enterprises (MSME). Development, News Release No. 2006/230/AFR. Retrieved on March 16, 2006, from http://www.worldbank.org/

World Bank. (2006). Micro, small, and medium enterprise competitiveness project. Retrieved on May 30, 2006, from http://web.worldbank.org/ 